\title{
MEDIEVAL MATERIALS AVAILABLE TO RUTGERS STUDENTS
}

\author{
BY PETER CHARANIS
}

Professor Charanis is a medievalist of national and international standing with particular interest in Byzantine history. With the Rutgers Department of History since $193^{8}$, he has published one book and about 30 articles and numerous book reviews. His articles include several long essays.

7 HE EXTENT to which a field of history can be cultivated in a University depends entirely upon its library resources. Among these, the primary sources come first, but various bibliographical aids, dictionaries, encyclopaedias, monographs and periodicals are also very important. The accumulation of this vast material is almost always haphazard, for it depends, assuming that the funds are available, upon the interests and scholarly competence of the faculty. For this reason rare are the University libraries whose holdings make possible the cultivation of every field of history.

Of the materials available to the history student at Rutgers University in New Brunswick, that in the field of medieval history, both Greek and Latin, is among the richest. This is largely because of the extensive holdings of the New Brunswick Theological Seminary and the important acquisitions which the Rutgers University Library has recently made. These holdings are by no means complete; important gaps exist among the primary sources, and more important still among the secondary. But the holdings include important collections of sources and sufficient of the secondary materials to enable the student to go very far.

Among the important collection of sources the following may be mentioned: Migne's Patrologiae, both Greek and Latin, the most complete collection of source material; the Corpus scriptorum ecclesiasticorum Latinorum, the great collection of the Latin church fathers to the seventh century; Mansi's Sacrorum conciliorum nova et amplissima collectio, the greatest collection of the records of the church councils; Acta sanctorum, a vast collection of biographies of saints, the most complete in existence; Collection de documents inédits sur l'histoire de France and Publications de la Société de l'histoire de France-two huge collections of sources of French history; Bouquet, Rerum Gallicarum et Francicarum scriptores, another great 
collection of sources on the history of France; the Monumenta Germaniae historica (500-1500), the most famous nineteenth century collection (still going on) of medieval sources; Muratori's Rerum Italicarum scriptores ab anno aerae christianae 500 ad 1500 , a vast and renowned collection of the sources of the medieval history of Italy; Recueil des historiens des croisades, the most complete collection of the sources of the Crusades; Corpus scriptorum historiae Byzantinae, the most used and most complete collection of the Byzantine historians; Sathas, Bibliotheca Graeca Medii Aevi and Documents inédits relatifs à l'histoire de la Grèce au moyen âge, two important collections of medieval Greek sources; Early English Text Society Publications; D'Achery-Mabillon, Acta Sanctorum Ordinis $S$. Benedicti, a collection of monastic documents; Pitra, Analecta Sacra, Analecta Novissima, and Spicilegium Solesmense, three important collections of Greek and Latin documents; Graffin and Naw, Patrologia Orientales, an important collection of oriental sources with translations in a European language, usually French or English; Krüger-Mommsen-Schoell, Corpus Juris Civilis, the famous codes of Justinian; Heinbach, Basilics, the Greek adaptation of the Corpus Juris Civilis; Zachariae von Lingenthal, Jus Graeco-Romanum, a collection of post Justinian legal documents; Friedberg's Corpus juris canonici, the best edition of the canon law; Gallia Christinia, an important collection of documents of ecclesiastical significance in the history of France; and also the two collections of miscellaneous materials brought together by Martene and Durand, viz, Thesaurus novus anecdotorum seu collectio monumentorum and Veterum scriptorum et monumentorum amplissima collectio. Worthy of mention is also the Analecta hymnica medii aevi, edited by $\mathrm{C}$. Blume and G. M. Dreves. Besides these great collections there are numerous lesser sets and one volume works which, of course, cannot be listed here. These holdings are very respectable indeed.

The secondary materials, though less extensive, include some important items. Among the bibliographical aids, Potthast's Bibliotheca historica medii aevi and Krumbacher's Geschichte der byzantinischen Literatur, and among the dictionaries, the two very important dictionaries of medieval Latin and Greek, Du Gange's Glossarium mediae et infimae latinitatis and Glossarium ad scriptores mediae et infimae graecitatis, should be mentioned. Besides the general encyclopaedias there are some special ones, as, for instance, the 
Dictionnaire de théologie catholique, the Dictionnaire d'archéologie chrétienne et de liturgie, the Dictionnaire d'histoire et de géographie ecclésiastique and the Jewish Encyclopaedia. The periodical holdings include, among others, complete or nearly complete sets of the following: Revue historique; Revue des questions historiques; Revue des études Juives; Revue des études byzantines; Le moyen âge; Analecta bollandiana; Historische Zeitschrift; Byzantinische Zeitschrift; Byzantion; Byzantino-Slavica; Byzantinisch-neugriechisch Jahrbücher; Isis; Speculum; Epeteris Hetaereias Byzantinon Spondon. The University library possesses also a complete set of the Sitzungsberichte (Philosophisch-historische Klasse) of the Academy of Vienna, one of the most important Academy publications of Europe. It possesses, in addition, a complete set of Subsidia Hagiographica, which consists of a series of monographs dealing with various aspects of the lives of the saints, a goodly number of volumes of another important series of monographs, the Abhandlungen (Philosophisch-historische Klasse) of the Academy of Berlin and a complete set of the monographs published by the Medieval Academy of America. To these series of monographs the University library has just added another and more important series, the renowned Denkschriften (Philos.-hist. Klasse) of the Academy of Vienna.

These holdings are respectable, but there are many important items that one would like to add to them. To the sets of periodicals, to give this as an example, one would like to add, among others, the following: Revue belge de philologie et d'histoire; Archivio storico italiano; Rivista storica italiana; Zeitschrift für Kirchengeschichte; Revue d'histoire ecclésiastique; Archivum franciscanum historicum; Revue d'histoire franciscaine; Revue d'histoire de l'église de France; Vierteljahrschrift für Sozial und Wirtschaftsgeschichte; Historisches Jahrbuch. If funds were available sets of these periodicals could, I am sure, be found. 